\title{
Agnieszka Sozańska-Ławniczak
}

UNIWERSYTET WROCŁAWSKI

\section{Literacki kontekst dzieła muzycznego}

\section{Chopinowska ballada versus Skriabinowski poemat}

Tematem moich zainteresowań badawczych jest korespondencja twórczości Fryderyka Chopina i Aleksandra Skriabina. Zwracając uwagę na zależności między dziełami reprezentującymi różne epoki, przyjmuję „ahistoryczną" koncepcję analizy muzycznej, umożliwiającą porównywanie i zestawianie obiektów bez uwzględnienia ich przynależności do danego okresu. W tym miejscu nasuwa się oczywiste skojarzenie z zaczerpniętą z literaturoznawstwa teorią intertekstualności, zdefiniowaną w 1967 roku przez bułgarską badaczkę Julię Kristevę ${ }^{1}$, zakładającą dialog między dziełami kultury, ich wzajemne inspiracje, fascynacje czy negacje. W niniejszym artykule chcę skoncentrować się na pewnym wycinku moich dotychczasowych badań nad twórczością Chopina i Skriabina w perspektywie intertekstualnej. Obejmuje on szczególnie interesujący aspekt dialogowania nie tylko między kompozytorami reprezentującymi kolejne generacje, ale także w obrębie różnych dziedzin sztuki. Tematem tej pracy jest bowiem analiza elementów literackich obecnych w dziele muzycznym, dokonana na przykładzie Chopinowskich ballad i Skriabinowskich poematów, zarówno fortepianowych, jak i symfonicznych.

W myśl interpretacji integralnej, stanowiącej dla mnie punkt wyjścia do analizy muzycznej, przedmiotem zainteresowania muzykologa jest dzieło rozumiane jako całość, a więc zarówno immanentnie (jako

1 J. Kristeva, Bakhtine, le mot, le dialogue et le roman, „Critique” xxxiII (1967), nr 239, s. 438-465. 
utwór per se), jak i kontekstualnie - dzieło obecne w przestrzeni kultury. Właśnie ten drugi aspekt pozwala widzieć związki nie tylko między różnymi wytworami działalności artystycznej, ale też między zupełnie odrębnymi dziedzinami sztuki, jak muzyka i literatura. Rozważania na temat ich relacji są zadaniem niełatwym, obarczonym ryzykiem powierzchowności sądów i nieprzystawalności stosowanej terminologii, przenoszonej z jednej dyscypliny na drugą. Wynika to z braku odpowiedniego warsztatu metodologicznego i uniwersalnych narzędzi pozwalających na równoważne zestawianie obu gałęzi sztuki. Według Michała Głowińskiego związki między literaturą a muzyką ujawniają się na kilka sposobów, m.in. za sprawą ,ich oddziaływania na siebie, przejmowania w utworach literackich muzycznych środków wyrazu i odpowiednio, w dziełach muzycznych - treści literackich"2. Nas oczywiście interesować będzie druga $\mathrm{z}$ wymienionych perspektyw. Należy pamiętać jednak, że w przypadku Skriabina granice między działalnością kompozytorską a pisarską nie są tak wyraźne. Chopinowskie ballady i Skriabinowskie poematy nie są dziełami wokalnymi, chociaż sporadycznie, np. w Prometeuszu Skriabina, pojawiają się w nich partie chóralne. Nie reprezentują też muzyki programowej w jej tradycyjnym rozumieniu mimo licznych prób takiej kwalifikacji. Związków z literaturą nie sposób im jednak odmówić, już choćby przez wzgląd na przywołanie literackich kategorii gatunkowych w tytułach utworów. Omawiane dzieła stanowią więc przykład innego niż romantyczne rozumienia zjawiska „literackości” muzyki, oznaczającego dla kompozytorów głębszy problem natury ontologicznej. Nie chodzi tu o wykorzystywanie tekstu literackiego w utworze wokalnym ani o nadawanie literackiego programu dziełom instrumentalnym, ale o literackość muzyki jako jedną z jej potencjalnych właściwości. Może się ona objawiać na różne sposoby lub też pozostać utajona. Jak zatem przemawia do nas z kart Chopinowskich ballad oraz poematów Skriabina?

Pierwszym i najbardziej widocznym śladem obecności literatury w muzyce obu twórców będzie wspomniane już wykorzystanie literackich kategorii gatunkowych jako tytułów utworów muzycznych. Nadając nazwy „ballady” czy „poematu”, kompozytorzy sugerują literackość dzieła, przywołują ją i podkreślają. Nie są na tym polu pierwsi ani szczególnie nowatorscy. Romantyczna nobilitacja gatunków

2 M. Głowiński, Literatura a muzyka, w: Słownik literatury polskiej xx wieku, red. A. Brodzka i in., Wrocław 1992, s. 548-549. 
literackich w muzyce była zjawiskiem powszechnym i wiązała się ze stopniowym wyczerpywaniem tradycyjnego repertuaru form i gatunków muzycznych w xIx wieku. Potrzeba sięgania do innych mediów, jak literatura czy malarstwo, stanowiła jeden z wyznaczników muzyki tej epoki. Samo wykorzystanie przez Chopina i Skriabina określonych gatunków literackich nie zakładało jednak wprowadzania do dzieła programu czy stosowania muzycznej ilustracyjności. Wskazówka gatunkowa miała jedynie naprowadzać słuchacza na właściwy trop interpretacyjny za sprawą pewnych konotacji, nie narzucając żadnych konkretnych treści. Można więc stwierdzić, że mamy tu do czynienia z tzw. literackością „nieprogramową", jak ten rodzaj relacji określa Michał Głowiński w swoim studium pt. Gatunki literackie w muzyce ${ }^{3}$. Zdaniem badacza wskazówka gatunkowa informuje o intencjach kompozytora i charakterze utworu, stając się tym samym kategorią estetyczną. W tym punkcie należy uznać pewną wspólnotę dążeń estetycznych Chopina i Skriabina, wykorzystujących literackie kategorie gatunkowe w celu poszerzenia granic muzyki i pogłębienia zawartych w niej treści. Na tym jednak podobieństwa wydają się kończyć, o czym szerzej w dalszej części pracy.

Analizę literackości dzieła muzycznego rozpoczęto w artykule od przywołania Chopinowskich ballad. Wydaje się pewne, że źródło inspiracji do stworzenia przez kompozytora tegoż gatunku stanowiła romantyczna ballada poetycka, czyli utwór z pogranicza liryki i epiki, pośredni między eposem a baśnią ludową, o elementach fantastycznych i dramatycznych4. Jej forma jest swobodna, nie ograniczona żadną aprioryczną konstrukcją, ale podlegająca dynamice zdarzeń. Niektóre definicje ballady podkreślają również jej szczególny nastrój, element niezwykle istotny z perspektywy wszelkiej twórczości muzycznej. Przekonanie o potrzebie wywoływania określonej atmosfery jako

3 Określenie zastosowane przez Michała Głowińskiego w rozważaniach na temat literackości muzyki i muzyczności literatury. Zob. M. Głowiński, Gatunki literackie w muzyce, [w:] tegoż, Prace wybrane, t. 2, Narracje literackie i nieliterackie, red. R. Nycz, Kraków 1997 (Klasycy Współczesnej Polskiej Myśli Humanistycznej). Badacz stawia taką „nieprogramową” literackość na antypodach programowości, utożsamianej w muzyce $\mathrm{z}$ gatunkiem poematu symfonicznego. Twierdzi ponadto, że poematy symfoniczne były dziełami programowymi ze względu na posiadane tytuły literackie.

4 Pełną definicję tego gatunku zob. w: S. Sierotwiński, Słownik terminów literackich. Teoria i nauki pomocnicze literatury, Wrocław 1986, s. 37. 
domenie wspólnej dla muzyki i literatury towarzyszyło zresztą badaczom związków słowno-muzycznych od końca xix wiekus. Wracając do przytoczonej definicji gatunku, już na podstawie choćby pobieżnej analizy muzykologicznej można z przekonaniem stwierdzić, że wszystkie cztery Chopinowskie ballady: g-moll op. 23 (1835-1836), F-dur op. 38 (1839), As-dur op. 47 (1841) i f-moll op. 52 (1842-43) spełniaja wymienione kryteria gatunkowe. Nie daje nam to jednak odpowiedzi na zasadnicze pytanie o istotę ich „literackości”.

Zdaniem Mieczysława Tomaszewskiego w muzyce Chopina prawie wszystko rozgrywa się w sferze konotacji. Jak już zostało wspomniane, samo określenie omawianych utworów mianem ballad budzi pewne skojarzenia oraz potęguje właściwości konotacyjne zawarte w muzyce, takie jak narracyjność, epickość czy balladowość. Słuchacz, sugerując się tytułem, zwraca zatem uwagę m.in. na tok narracyjny utworu. Aby w pełni zrozumieć fenomen narracyjności muzyki, należałoby sięgnąć do wypowiedzi samego Chopina zawartych w jego Szkicach do metody gry na fortepianie. Kompozytorowi całe życie towarzyszyło przekonanie o pokrewieństwie między muzyką a mową, przy czym jego zdaniem „słowo narodziło się z dźwięku, dźwięk istniał przed słowem”'. Muzyka stanowiła dla Chopina mowę bez słów, swego rodzaju superjęzyk, za pomocą którego przekazywał „wrażenia, uczucia i myśli”’ W W kręgach artysty podkreślano znaczenie frazy lub inaczej - myśli muzycznej jako istoty jego utworów, o czym wspomina Ryszard Przybylski w eseju pt. Cień jaskółki. Zestawiając muzykę kompozytora z antytetyczną twórczością Hectora Berlioza, Przybylski zauważa: „Chopin nie znosił więc utworów, w których brzmienie zastępowało «myśl muzyczną», najwyraźniej utożsamianą z tematem, a raczej z melodią"8. Chopinowskie myśli muzyczne czy, ogólniej mówiąc, tematy, stanowiły źródło akcji balladowej; dialogowały ze sobą, przeplatały się lub zderzały, prowadząc do potężnych kulminacji. Myśl muzyczna była dla kompozytora odzwierciedleniem refleksji osobistej, podobnie jak strofy wiersza stanowią odbicie przeżyć wewnętrznych poety. Takie podejście wyjaśniałoby szczególną ekspresję i nasycenie emocjonalne jego ballad. Co istotne,

5 Zob. M. Bristiger, Związki muzyki ze słowem. Z zagadnień analizy muzycznej, Warszawa 1986, s. 15.

6 F. Chopin, Szkice do metody gry fortepianowej, tłum. Z. Skowron, Kraków 1995, s. 14.

7 Tamże.

8 R. Przybylski, Cień jaskółki. Esej o myślach Chopina, Kraków 2009, s. 190. 
interpretacja owych uczuć i myśli zapisanych w dźwiękach wprowadza nasz dyskurs w sferę recepcji, która w xıx wieku często wpisywała się $\mathrm{w}$ tendencję do semantycznego odczytania dzieła muzycznego' ${ }^{9}$. Nie dziwi więc powszechne i nadal funkcjonujące w zbiorowej świadomości słuchaczy przypisywanie balladom Chopina treści programowych zaczerpniętych z analogicznych dzieł Mickiewicza, stanowiących dla kompozytora istotny element romantycznego dziedzictwa. Praktyka ta posiada zresztą długą tradycję badawczą, zapoczątkowaną jeszcze przez Roberta Schumanna, a kontynuowaną m.in. przez takich badaczy jak James Huneker, czy współcześnie Antoni Tucholski. Większość wypowiedzi muzykologów na omawiany temat cechuje jednak dość znaczna swoboda, wynikająca z braku poparcia teorii szczegółową analizą muzykologiczną. Ponadto błąd w postaci dobierania konkretnego utworu literackiego jako programu chopinowskich kompozycji wynika z niewłaściwego rozumienia stosunku artysty do istoty muzyki. Chopin opowiada dźwiękami, a stworzona przez niego muzyka tworzy narrację; nie skupia się ona jednak na konkretnych zdarzeniach, ale na samej sobie. Należy zatem postawić pytanie w jaki sposób i za pomocą jakich środków muzycznych Chopin snuje swoją opowieść, nie zaś domniemywać o czym ta opowieść jest. Badania nad narracyjnością w kompozycjach Chopina mają już swoją tradycję, zapoczątkowaną m.in. przez prace Eera Tarastiego, który przeniósł system analityczny semiotyki strukturalnej na utwory reprezentujące formy swobodne ${ }^{10}$. Nie streszczając tu jego koncepcji ani nie zagłębiając się w szczegółową analizę, warto wspomnieć o elemencie stanowiącym jeden z podstawowych budulców narracji w muzyce. Dla Chopina będzie to czynnik ruchowy; ruch wstępujący lub zstępujący, rozgrywający się w czasie i wyznaczający kolejne fazy opowieści. Związany jest on $\mathrm{z}$ innymi elementami dzieła muzycznego wzmacniającymi jego emocjonalny przekaz: dynamiką, agogiką, odpowiednio dobraną harmoniką i fakturą. We wszystkich czterech balladach zauważyć można różne pod

9 O semantyzacji struktury dźwiękowej w xIx wieku pisze Irena Poniatowska w swoim studium $W$ kręgu recepcji i rezonansu. Szkice chopinowskie, Warszawa 2008. Poniatowska zwraca uwagę na to, że większość programów i tytułów dzieł romantycznych była produktem recepcji, wpisując się w tzw. narodowy model interpretacji.

10 Eero Tarasti zinterpretował z punktu widzenia teorii narratologii m.in. Ballade g-moll Chopina. Zob. E. Tarasti, A narrative grammar of Chopin's G minor Ballade, "Chopin Studies" 1995, t. 5., s. 38-63. 
względem kierunku rozwoju sposoby prowadzenia narracji: od stopniowego budowania napięcia prowadzącego do potężnej kulminacji w finale utworu (Ballada g-moll op. 23, Ballada f-moll op. 52), przez nieustanną grę przeobrażających się tematów (Ballada As-dur op. 47), aż po gwałtowne zderzenia antytetycznych pod względem ekspresji części utworu z zaskakującą kodą w pianissimo (Ballada F-dur op. 38).

Prócz wspomnianej narracyjności kolejnym skojarzeniem gatunkowym towarzyszącym balladom Chopina jest charakterystyczny ton balladowy, na który składają się takie kategorie ekspresyjne jak dramatyczność, tajemniczość, nastrojowość i refleksyjność, obecne we wszystkich czterech dziełach kompozytora. Jak twierdzi Tomaszewski, zdaje się on „streszczać i ucieleśniać idiom ballady poetyckiej, z jej tajemniczością, surrealnością, niesamowitością i grozą" ${ }^{11}$. Muzyka Chopina odmalowuje nastroje właściwe dla gatunku ballady poetyckiej przede wszystkim za pomocą kategorii kontrastu, przenikającego wszystkie elementy dzieła muzycznego. Zaskakujące zmiany nastrojów osiągane są przez wykorzystanie nietypowych zmian tonacji oraz zestawianie odcinków zróżnicowanych fakturalnie, agogicznie i dynamicznie. Przykładem utworu, w którym kontrast stanowi podstawowy wyznacznik formy i ekspresji całego dzieła, jest druga Ballada F-dur op. 38, zbudowana na zasadzie zderzenia dwóch odmiennych tematów tworzących zasadniczo inne światy brzmieniowe i wyrazowe.

Ostatnią specyficzną własnością Chopinowskich ballad wiążącą je z literackim pierwowzorem jest epickość, kategoria zespolona $\mathrm{z}$ opowieścią o minionych wydarzeniach, często istotnych dziejowo, naznaczonych aurą tajemniczości na wzór ludowych baśni i podań. Epickość rozumiemy także jako rozległość opisu i swego rodzaju swobodny rozmach w prowadzeniu narracji - właściwości charakterystycznych również dla dzieł Chopina. Nie bez powodu do słownika muzykologicznego wszedł zwyczaj określania jego ballad mianem poematów fortepianowych. W ten sposób podkreślany jest nie tylko rozmiar, ale również znaczenie kompozycji, zapowiadających swym rozmiarem i samym sposobem konstruowania formy tak popularne $\mathrm{w}$ drugiej połowie xIx wieku poematy symfoniczne.

Gatunek ten płynnie wprowadza nas w twórczość rosyjskiego kompozytora Aleksandra Skriabina, szeroko czerpiącego z Chopinowskiej spuścizny. Sięgnięcie do gatunku poematu, początkowo fortepianowego

11 M. Tomaszewski, Chopin. Człowiek, dzieło, rezonans, Kraków 2005, s. 458. 
(aż dziesięć opusów), a następnie symfonicznego (trzy ostatnie dzieła), zbiega się z powstaniem przełomowej III Symfonii c-moll o podtytule Boski Poemat (1904). Skomponowane w 1903 roku poematy fortepianowe Tragique op. 34 i Satanique op. 36 przygotowują Skriabina do tego wielkiego dzieła, zapoczątkowując fazę „poematowości” w jego twórczości. Skąd jednak pomysł wykorzystania właśnie tego gatunku i jego rosnąca popularność w wyborach artystycznych rosyjskiego kompozytora? Pojawienie się poematu w twórczości Skriabina zbiega się z rozwojem jego zainteresowań filozoficznych, m.in. pod wpływem nasilonych kontaktów ze środowiskiem rosyjskich symbolistów, chętnie sięgających do tzw. poematu prozą. Wspólną płaszczyznę dla Skriabina i symbolistów stanowiły podobne rozterki i pytania stawiane sztuce, jak choćby relacja przekładalności muzyki i literatury. Według symbolistów polem, na którym odbywał się dialog tych dwóch sztuk, miała być filozofia: „Muzyka zaś, ta zapisana w nutach, wyznacza «tylko i aż» drogowskazy (...) filozoficznej i mistycznej "podróży»"12. Jak twierdzi Grażyna Bobilewicz-Bryś w swoim studium poświęconym twórczości rosyjskich symbolistów: „stojąc wobec przekładalności obu sztuk, symboliści stosują w swych interpretacjach «kwalifikatory» zaczerpnięte z innych dyscyplin: filozofii, religii oraz psychologii" ${ }^{13}$. Filozofia, będąc najbardziej uniwersalną z wymienionych dziedzin, pozwala interpretować dzieło muzyczne i poetyckie za pomocą tych samych narzędzi, niwelując tradycyjne podziały między różnymi gałęziami sztuki i dążąc do ich syntezy, której ostateczną realizację miało stanowić wielkie synkretyczne dzieło - Misterium. Postulowana koncepcja syntezy sztuk była realizacją związków literacko-muzycznych na płaszczyźnie ideologicznej. Jednym z konkretnych działań mających na celu wdrożenie opisanej idei w życie było opracowanie przez Skriabina projektu fortepianu świetlnego (clavier à lumière). Choć próba rzeczywistej realizacji estetyczno-filozoficznej koncepcji Skriabina nie powiodła się, powstał jednak instrument inspirowany pomysłem kompozytora ${ }^{14}$.

12 T. Baranowski, Profile Skriabina, Białystok 2013, s. 122.

13 G. Bobilewicz-Bryś, Aleksander Skriabin w myśli estetycznej i twórczości symbolistów rosyjskich, „Slavia Orientalis” 1993, nr 1, s. 32.

14 W Muzeum Aleksandra Skriabina w Moskwie znajdują się 12-lampowe organy skonstruowane po śmierci kompozytora przez zaprzyjaźnionego profesora Aleksandra Mozera. 
Wymienione czynniki wskazują na dalece odmienne od Chopinowskiego podejście Skriabina do związków między muzyką a literaturą. Dla niego były one realizacją głębszej myśli filozoficznej, dla polskiego kompozytora zaś wynikały z fascynacji literaturą i charakterystyczną dla twórczości romantycznej próbą pogłębienia zawartych w muzyce treści za sprawą dodatkowego medium.

Istotne miejsce muzyki w dorobku symbolistów wynikało ze świadomości niedoskonałości języka jako narzędzia ekspresji. Z punktu widzenia poety muzyka wspomaga więc tekst literacki poprzez uwypuklenie jego strony brzmieniowej oraz przekazywanie metafizycznej zawartości poezji. W twórczości Skriabina, przede wszystkim kompozytora i pianisty, mamy raczej do czynienia z odwrotną proporcją: tu poezja dopełnia stronę muzyczną dzieła. Słowo wiąże się z muzyką na płaszczyźnie wewnętrznej, ukrytej. Tekst poetycki czy program, często dołączany do poematów ex post (np. Poemat Ekstazy op. 54, 1905-1907) lub zastępowany po pewnym czasie nowym, nie ma bezpośredniego związku z dźwiękiem, ale służy dopełnieniu wyrazowemu muzyki, stanowi rodzaj komentarza do dźwięków. Tę tezę zdaje się potwierdzać podejście Skriabina do partii wokalnych swoich kompozycji, w których chór sprowadzany jest do roli tłumu wykonującego wokalizy i okrzyki (Prometeusz. Poemat ognia op. 60, 1909-1910). Podobny przykład stanowi bardzo trudne do „umuzycznienia” libretto (L'Acte prealable) do nigdy nieukończonego opus vitae kompozytora - wielkiego Misterium. Wydaje się, że Skriabin, ukierunkowując wyobraźnię słuchacza za sprawą tytułów czy poetyckich komentarzy, stara się poszerzyć granice muzyki w celu jej lepszego i pełniejszego odczytania, jak w Prometeuszu, dziele nawiązującym do mitologii greckiej. Warstwa treściowa zawarta w literackich komentarzach Skriabina skupia się wokół takich zagadnień, jak Nietzscheańska wola mocy, mistyczna ekstaza, czy koncepcja Człowieka-Boga, pozostaje więc bezpośrednio złączona z filozoficznymi zainteresowaniami kompozytora.

Już samo przywołanie kategorii gatunkowej poematu ma na celu skierowanie uwagi słuchacza na dodatkowe medium, jakim jest poezja, za pomocą której kompozytor przekazuje swoje filozoficzne refleksje. Według modernistycznej koncepcji sztuki brzmienie było zewnętrznym przejawem tego, co wewnętrzne, a tekst słowny stanowił jedynie komentarz do owego wewnętrznego przekazu. Nie sposób w tym miejscu nie dostrzec, że w twórczości symfonicznej Skriabina 
dokonuje się stopniowa subiektywizacja języka muzycznego, prowadząca aż do mistycznej koncepcji dzieła jako religijnego misterium. Osobisty i refleksyjny charakter utworów rosyjskiego kompozytora, zbieżny z przekazem estetyczno-ideowym tak popularnych w kręgu symbolistów poematów prozą, utwierdza nas w przekonaniu o literackiej proweniencji poematu w jego dorobku artystycznym. Tomasz Baranowski idzie w swoich rozważaniach o krok dalej, przyjmując tezę, że „Skriabin był niejako twórcą tego kierunku [symbolizmu - przyp. A.S.Ł.] w dziejach literatury początku xx stulecia"15. Silne związki $\mathrm{z}$ symbolizmem kierują nasze rozważania $\mathrm{w}$ stronę poetyckości jako cechy właściwej dla wszelkiej aktywności twórczej kompozytora - muzycznej, literackiej czy filozoficznej.

Analiza samych tylko poematów rosyjskiego kompozytora pozwala zauważyć w ich warstwie muzycznej takie charakterystyczne wyznaczniki jak ekstatyczna melodyka, nagromadzenie chromatyki i środków polifonicznych, stałe napięcie harmoniczne i tendencja do wznoszącego kierunku ruchu harmonicznego ${ }^{16}$ związana z próbą ucieczki od rzeczywistości w stronę transcendencji. Nastrój utworu osiągany jest także przez odpowiednio dobraną instrumentację $\mathrm{w}$ dziełach orkiestrowych i umiejętne wykorzystywanie technicznych możliwości fortepianu w utworach solowych, m.in. poprzez stosowanie skomplikowanej i zindywidualizowanej pedalizacji. Wymienione środki ekspresji są nierozerwalnie związane z barwą brzmienia, choć Skriabin wprowadził do swoich poematów również rozwiązania z zakresu symboliki muzycznej, takie jak słynny akord prometejski $(c-d-e-f i s-a-b)$ stanowiący centrum brzmieniowe całego utworu (Prometeusz). Te czynniki tworzą metaforyczne dopełnienie tekstu muzycznego, podobnie jak poetyckość wiersza czy literatury wzbogaca go o element wyobrażeniowy, symboliczny. Charakterystyczne dla dzieła Skriabina jest również tytułowanie motywów przewodnich i tematów, np. temat "marzenia”, „wzlotu”, „woli” (Poemat Ekstazy), oraz stosowanie bogatego słownika poetyckich określeń wyrazowych czy wskazówek wykonawczych. W partyturach interesujących nas dzieł, m.in. W III Symfonii „Boski

15 T. Baranowski, dz. cyt., s. 149.

16 Szerzej na temat znaczenia wnoszącego kierunku ruchu harmonicznego u Skriabina i Chopina traktuje tekst rosyjskiego badacza Н. Ханнанова: Восходящее направление в гармонии Шопена и Скрябина и его семантика, [w:] Ученные записки, t. 7, cz. 1, Мемориальный Музей А.Н. Скриабина, Москва 2012. 
Poemat", kompozytor stosuje tak wyrafinowane określenia wykonawcze, jak „z rozmarzeniem”, „mistycznie”, „tragicznie” czy „bosko”. Opisane bogactwo metafor i środków stylistycznych po raz kolejny przywodzi na myśl poemat prozą, jeden z ulubionych gatunków artystów „,srebrnego wieku", takich jak Andriej Bieły czy Wiaczesław Iwanow. Gatunek ten, obejmujący utwory refleksyjne lub osobiste, odznacza się zwartą, choć niepoddaną rygorom mowy wierszowanej konstrukcją oraz bogactwem poetyckich określeń wyrazowych. Skriabinowskie poematy wpisują się także w założenia estetyczne gatunku poematu lirycznego, przeważnie afabularnego utworu, którego tematem są osobiste doznania, refleksje i wrażenia autora. Poematy takie również odznaczały się swobodną kompozycją i bogactwem środków stylistycznych.

Wymienione przesłanki pozwalają stwierdzić, że poematy symfoniczne Skriabina nie reprezentują tradycyjnie rozumianego gatunku romantycznego związanego z programowością, ale stanowią rodzaj muzycznego wyznania, w którym za pomocą kategorii poetyckich kompozytor wyraża osobiste refleksje, koncepcje filozoficzne czy idee. Należy zwrócić uwagę na odmienne od chopinowskiego rozumienie literackości dzieła muzycznego. O ile w balladach Chopina literackość egzemplifikuje się poprzez zastosowanie zaczerpniętych z literatury kategorii gatunkowych wraz z ich charakterystycznymi wyznacznikami, o tyle u Skriabina prócz gatunkowego nawiązania istnieje szereg innych argumentów potwierdzających silne związki muzyki z poezją. Są to związki dwustronne. Z jednej strony muzyka rosyjskiego kompozytora stanowi dopełnienie tekstu poetyckiego, stając się jego wyrazicielką. Przykładem takiej tendencji może być libretto L’Acte prealable, stanowiące zapis pierwotnej wobec muzyki idei wielkiego, nigdy niezrealizowanego misterium. W twórczości rosyjskiego kompozytora przeważa jednak odwrotna praktyka: muzyka to sedno jego twórczości, zaś poetyckie określenia wykonawcze, programy pisane do gotowych już utworów czy tytuły tematów i dzieł stanowią jej uzupełnienie i pogłębienie. Jednak bez względu na to, w jaki sposób wyznaczymy punkty ciężkości na mapie muzycznej i poetyckiej aktywności Skriabina, należy zdać sobie sprawę z ich podporządkowania wyższej idei, a mianowicie duchowej przemianie jednostki i całej ludzkości.

Mimo wymienionych różnic można zauważyć także pewne istotne podobieństwo w podejściu Chopina i Skriabina do zjawiska literackości w muzyce. Kompozytorów łączy przede wszystkim sceptycyzm wobec 
romantycznej programowości, jej miejsce zajmuje zaś dążenie do wyjścia poza muzyczne tworzywo i przezwyciężenia jego ograniczeń za sprawą literackich, a ściślej - poetyckich konotacji.

\section{Bibliografia}

Baranowski T., Profile Skriabina, Białystok 2013.

Bobilewicz-Bryś G., Aleksander Skriabin w myśli estetycznej i twórczości symbolistów rosyjskich, „Slavia Orientalis” 1993, $\mathrm{nr} 1$.

Bristiger M., Związki muzyki ze słowem. Zzagadnień analizy muzycznej, Warszawa 1986.

Chomiński J.M., Kolorystyka dźwiękowa Skriabina, „Muzyka” 1959, nr 2. Chopin F., Szkice do metody gry fortepianowej, tłum. Z. Skowron, Kraków 1995.

Genette G., Paratexts. Thresholds of interpretation, Cambridge 2001.

Głowiński M., Gatunki literackie i nieliterackie, [w:] tegoż, Prace wybrane, t. 2, Narracje literackie i nieliterackie, red. R. Nycz, Kraków 1997 (Klasycy Współczesnej Polskiej Myśli Humanistycznej).

Głowiński M., Literatura a muzyka, w: Słownik literatury polskiej xx wieku, red. A. Brodzka i in., Wrocław 1992.

Głowiński M., Literackość muzyki - muzyczność literatury, [w:] Pogranicza i korespondencje sztuk. Studia, red. T. Cieślikowska, J. Sławiński, Wrocław 1980.

Gołąb M., Spór o granice poznania dzieła muzycznego, Wrocław 2003. Ханнанов Н., Восходящее направление в гармонии Шопена и Скрябина и его семантика, [w:] Ученные записки, t. 7, сz. 1, Мемориальный Музей А.Н. Скриабина, Москва 2012.

Hejmej A., Muzyka w literaturze. Perspektywy komparatystyki interdyscyplinarnej, Kraków 2012.

Nycz R., Intertekstualność i jej zakresy: teksty, gatunki, światy, [w:] tegoż, Tekstowy świat. Poststrukturalizm a wiedza o literaturze, Kraków 2000.

Poniatowska I., $W$ kręgu recepcji i rezonansu muzyki. Szkice chopinowskie, Warszawa 2008.

Przybylski R., Cień jaskółki. Esej o myślach Chopina, Kraków 2009.

Рубцова В.В., Скпябин и русский поэтический симболизм, [w:] Ученные записки, t. 1, Мемориальный Музей А.Н. Скриабина, Москва 1993. 
Scher S.P., Literature and music, [w:] Interrelations of Literature, red. J.-P. Baricelli, J. Gibaldi, New York, 1982.

Sierotwiński S., Stownik terminów literackich. Teoria i nauki pomocnicze, Wrocław 1986.Tomaszewski M., Chopin. Człowiek, dzieło, rezonans, Kraków 2005.

Tarasti E., A narrative grammar of Chopin's G minor Ballade, „Chopin Studies" 1995, t. 5., s. 38-63.

Tomaszewski M., Muzyka w dialogu ze słowem. Próby, szkice, interpretacje, Kraków 2003.

Tomaszewski M., Interpretacja integralna dzieła muzycznego, Kraków 2010.

\section{Abstract}

\section{Literary context of music composition. Chopin's ballad vs. Scriabin's poem}

The following article describes a phenomenon of the correspondence of arts using the works of Frederic Chopin and Alexander Scriabin as an example. The author is interested in the relations between music and literature and Chopin's ballads and Scriabin's piano poems, the genres, which are an effect of such relations. The analysis of those works shows that both composers have a different understanding of the essence of music and literature but there are also similarities. The ballads and poems do not convey a literary programme or music illustration but their sound matter is additionally complemented by the genre category, title or commentary instead.

Keywords: Chopin, Scriabin, ballade, narrative poem, intertextuality 